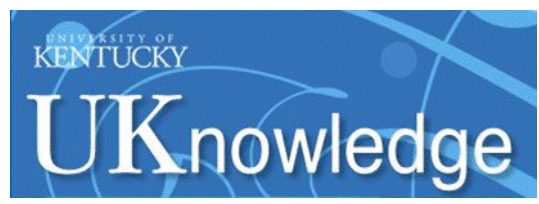

University of Kentucky

UKnowledge

Sanders-Brown Center on Aging Faculty

Publications

Aging

$1-2018$

\title{
Down Syndrome, Beta-Amyloid and Neuroimaging
}

\author{
Elizabeth Head \\ University of Kentucky, elizabeth.head@uky.edu
}

Alex M. Helman

University of Kentucky, amhelman99@gmail.com

David K. Powell

University of Kentucky, david.k.powell@uky.edu

Frederick A. Schmitt

University of Kentucky, fascom@uky.edu

Follow this and additional works at: https://uknowledge.uky.edu/sbcoa_facpub

Part of the Neurosciences Commons, and the Pathology Commons

Right click to open a feedback form in a new tab to let us know how this document benefits you.

\section{Repository Citation}

Head, Elizabeth; Helman, Alex M.; Powell, David K.; and Schmitt, Frederick A., "Down Syndrome, BetaAmyloid and Neuroimaging" (2018). Sanders-Brown Center on Aging Faculty Publications. 120.

https://uknowledge.uky.edu/sbcoa_facpub/120

This Article is brought to you for free and open access by the Aging at UKnowledge. It has been accepted for inclusion in Sanders-Brown Center on Aging Faculty Publications by an authorized administrator of UKnowledge. For more information, please contact UKnowledge@lsv.uky.edu. 
Down Syndrome, Beta-Amyloid and Neuroimaging

Digital Object Identifier (DOI)

https://doi.org/10.1016/j.freeradbiomed.2017.09.013

Notes/Citation Information

Published in Free Radical Biology and Medicine, v. 114, p. 102-109.

(๖ 2017 Elsevier Inc. All rights reserved.

This manuscript version is made available under the CC-BY-NC-ND 4.0 license

https://creativecommons.org/licenses/by-nc-nd/4.0/.

The document available for download is the author's post-peer-review final draft of the article.

This article is available at UKnowledge: https://uknowledge.uky.edu/sbcoa_facpub/120 


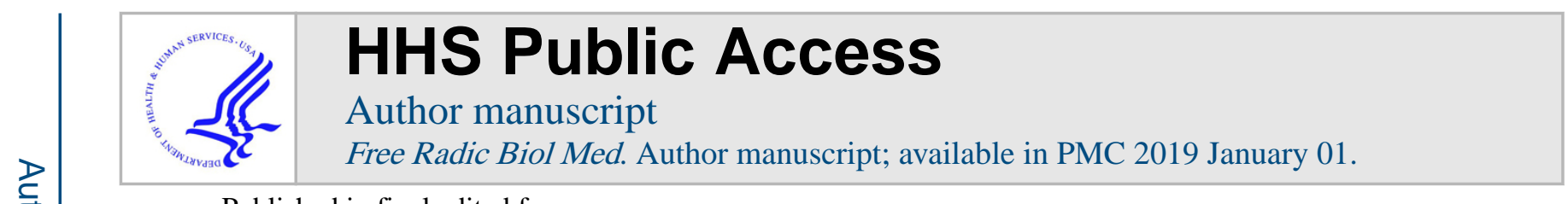

Published in final edited form as:

Free Radic Biol Med. 2018 January ; 114: 102-109. doi:10.1016/j.freeradbiomed.2017.09.013.

\section{Down syndrome, beta-amyloid and neuroimaging}

Elizabeth Head ${ }^{1,2}$, Alex Helman, David Powell ${ }^{3}$, and Frederick Schmitt ${ }^{1,4}$

${ }^{1}$ Sanders-Brown Center on Aging, University of Kentucky, Lexington, KY, 40536

${ }^{2}$ Department of Pharmacology \& Nutritional Sciences, University of Kentucky, Lexington, KY, 40536

${ }^{3}$ Magnetic Resonance Imaging and Spectroscopy Center, University of Kentucky, Lexington, KY, 40536

${ }^{4}$ Department of Neurology, University of Kentucky, Lexington, KY, 40536

\section{Abstract}

This review focuses on the role of $\mathrm{A} \beta$ in $\mathrm{AD}$ pathogenesis in Down syndrome and current approaches for imaging $A \beta$ in vivo. We will describe how $A \beta$ deposits with age, the posttranslational modifications that can occur, and detection in biofluids. Three unique case studies describing partial trisomy 21 cases without APP triplication, and the occurrences of low level mosaic trisomy 21 in an early onset AD patient are presented. Brain imaging for $A \beta$ includes those by positron emission tomography and ligands (Pittsburgh Compound B, Florbetapir, and FDDNP) that bind $A \beta$ have been published and are summarized here. In combination, we have learned a great deal about $A \beta$ in DS in terms of characterizing age of onset of this pathology and it is exciting to note that there is a clinical trial in DS targeting A $\beta$ that may lead to clinical benefits.

\section{Graphical Abstract}

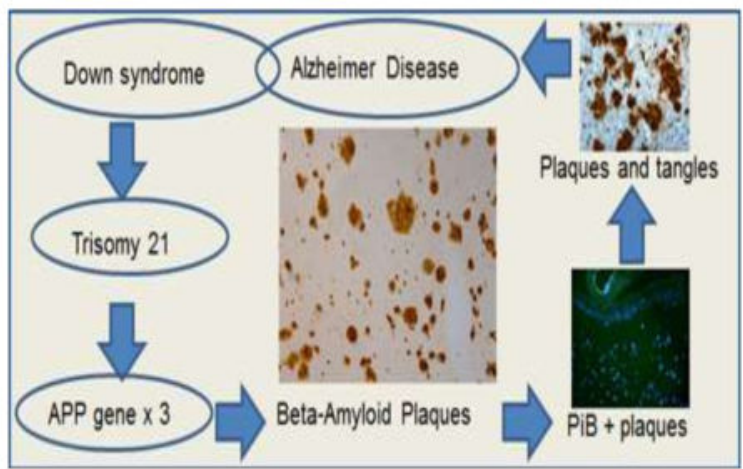

Corresponding Author: Elizabeth Head, PhD, University of Kentucky, Sanders Brown Center on Aging, 800 South Limestone Street, Lexington, KY, 40536, Phone: 859-218-3172, Fax: 859-323-2866, elizabeth.head@uky.edu.

Publisher's Disclaimer: This is a PDF file of an unedited manuscript that has been accepted for publication. As a service to our customers we are providing this early version of the manuscript. The manuscript will undergo copyediting, typesetting, and review of the resulting proof before it is published in its final citable form. Please note that during the production process errors may be discovered which could affect the content, and all legal disclaimers that apply to the journal pertain. 


\section{Keywords}

cerebrovascular pathology; neuroimaging; partial trisomy 21; Pittsburgh Compound B; trisomy 21

\section{Introduction}

Improved medical care for people with Down syndrome (DS) has led to a significant extension in lifespan and improved quality of life [1-3]. However, as people with DS reach their 40's and 50's, they are vulnerable to the development of Alzheimer disease (AD). Increased frequency of $\mathrm{AD}$ in $\mathrm{DS}$ may be related to two key factors: (1) aging, which is a risk factor for $\mathrm{AD}$ in the general population and; (2) trisomy in genes associated with $\mathrm{AD}$, particularly the APP gene.

AD was first described by Alois Alzheimer in 1901 (see [4] for an excellent review). We have since learned that a key protein engaged in $A D$ pathogenesis is beta-amyloid $(A \beta)$. One of the current working hypotheses is that $\mathrm{A} \beta$ is a critical initiator of $\mathrm{AD}[5,6]$.

Although this original hypothesis has been revised over time, due in part to the outcomes of recent clinical trials in $\mathrm{AD}$ targeting $\mathrm{A} \beta$ leading to little improvement in cognition[7], it is still considered a major contributor in the disease [8]. This review discusses the more recent developments regarding the role of A $\beta$ in DS both at a molecular level and through neuroimaging as several reviews on both of these topics have been published elsewhere [9$11]$.

\section{APP and Chromosome 21}

$\mathrm{A} \beta$ is produced from a longer amyloid precursor protein (APP) $[12,13]$, which is present on chromosome 21 and thus triplicated in DS [14, 15](Figure 1). It is interesting to note that one of the first descriptions of the biochemical properties of $A \beta$ were from samples isolated from DS brain $[16,17]$. In the nonamyloidogenic processing pathway, APP is first cleaved by $a$-secretase to form sAPPa and subsequently cleaved by $\gamma$-secretase to produce $\mathrm{p} 3$ and AICD (APP intracellular domain). This form of APP processing prevents the production of A $\beta$. However, in the amyloidogenic pathway, APP is first cleaved first by $\beta$-secretase to produce sAPP $\beta$ followed by $\gamma$-secretase cleavage yielding A $\beta$ and AICD. The $\beta$-secretase enzyme has been identified as beta-site APP cleaving enzyme or BACE1 [18] and $\gamma$ secretase consists of a complex that includes presenilin 1, nicastrin, PEN 2 and APH-1 [19].

In DS, the levels of brain $A \beta$ are significantly higher when compared to controls at young ages [20] and $A \beta$ increases exponentially with age [21,22] after 40 years. Increasing agedependent A $\beta$ in DS could be hypothesized as due to increasing APP production with age, increased $\beta$ - or $\gamma$-secretase activity or reduced degradation (discussed later). In an autopsy study of 36 cases with DS, $\alpha$-secretase activity appears to be relatively stable except in cases over 40 years of age who show a decline [22]. In contrast, studies of $\beta$-secretase activity show an increase with age [22] or show modest increases in protein level [23]. Further, total APP levels do not appear to change with age despite being higher in DS overall, suggesting that APP overexpression may be the primary driver of $A \beta$ plaque accumulation [24, 25]. 
A protein homologous to BACE 1, BACE2, can also cleave APP at the $\beta$-secretase site [26]. BACE- 2 is also located on chromosome 21 and may potentially contribute to increased A $\beta$ production in DS. In DS fetal tissue, BACE-2 RNA levels are significantly higher relative to controls [27]. In addition, in cultured fibroblasts from adults with DS, BACE-2 mRNA (i.e. protein expression) was 2.6 fold higher than normal controls. In 13 individuals with DS ranging in age from 27 weeks to 37 years, frontal cortex BACE-2 immunoreactivity was observed only in neurons of adults with DS and AD. BACE-2 immunoreactivity was not observed in younger individuals [28]. However, several studies comparing DS brain to similarly aged control brains do not find higher levels of BACE2 protein overall [24, 29]. Similarly, no differences in DS as compared to controls was observed for BACE2 in the intracellular compartment [27]. It is therefore possible that despite increased RNA for BACE2 in DS, there may be posttranscriptional regulatory mechanisms that lead to normal levels of BACE 2 or that increase the degradation of this enzyme [25]. Thus, APP overexpression and production of $\mathrm{A} \beta$ may be the primary driver of accumulation with age in DS $[24,25]$.

\section{Soluble $A \beta$ and oligomers in DS}

Once A $\beta$ is cleaved from APP it appears in soluble forms that can be detected either within neurons or in the extracellular space. Higher levels of soluble A $\beta$ are observed in DS fetal tissue relative to tissue from controls [20]. $A \beta$ can assemble into oligomers, protofibrils and A $\beta$-derived diffusible ligands (ADDLs) [30, 31](Figure 2). Importantly, A $\beta$ oligomers cause neuronal dysfunction prior to overt neuron loss [32]. Both biochemical and immunohistochemical experiments reveal significant amounts of oligomeric $\mathrm{A} \beta$ in the $\mathrm{AD}$ brain [33-35].

In DS frontal cortex, the amount of soluble $\mathrm{A} \beta 40$ and $\mathrm{A} \beta 42$ is higher in DS relative to controls [36, 37]. Interestingly, phosphate buffered saline (PBS) extracted soluble A $\beta 40$ in the frontal cortex increases in an exponential function with age in DS, particularly after age 40 years [21]. However, soluble A $\beta 42$ declines with increasing age but with a parallel increase in insoluble $A \beta 42$ suggesting sequestration into plaques [21]. PBS soluble $A \beta 40 / 42$ was also not different between DS and control cases in a study by Miners et al.[23]. Water soluble $\mathrm{A} \beta$ also appears to include modifications to $\mathrm{N}$-terminal glutamates [38].

Oligomeric $A \beta$ also accumulates exponentially after the age of 40 years [21]. Further, increasing amounts of oligomeric $\mathrm{A} \beta$ in DS frontal cortex is associated with lower synaptophysin protein levels, suggesting impaired synaptic function [39]. Soluble and insoluble $A \beta$ fibrils are also present in higher levels in aged DS cases with AD neuropathology compared to similarly aged control cases [40]. Thus, oligomeric A $\beta$ may play a critical role in causing neuron dysfunction during both development and aging in DS. Indeed, a recent study in the Ts65Dn mouse using environmental enrichment, led to reduced hippocampal oligomers and improved cognition [41]. 


\section{Intracellular A $\beta$ in DS}

Although a large amount of $\mathrm{A} \beta$ exists in a soluble form, insoluble deposits also begin to progressively form over time. However, the subcellular location for these events is less well understood [42], particularly in DS, which has been discussed in a previous review and is updated here [10]. Gyure et al (2001) report intracellular $A \beta 1-40$ but not $A \beta 1-42$ [43]. In contrast, other studies report intracellular $A \beta 1-42$ but not $A \beta 1-40[44,45]$, which in one study was clearly distinguished from intracellular APP immunoreactivity [44]. A report by Hirayama et al. found neither $A \beta 1-40$ nor $A \beta 1-42$ but observed intracellular $A \beta 1-43$ [46]. Each length of $A \beta$ has different properties. $A \beta 1-40$ is more rapidly degraded within lysosomes than the longer, more toxic $A \beta 1-42 / 43[47,48]$. The reasons for observations of different length $A \beta$ species in intracellular deposits in each of these studies may therefore be due in part to technical differences.

A common observation in the majority of the studies of intracellular A $\beta$ in DS is the early age of onset; both infants and children with DS accumulate intracellular $A \beta$. In addition, intracellular $A \beta$ is consistently observed prior to the accumulation of extracellular $A \beta$ deposits [44], which parallels reports in transgenic mouse models of $\mathrm{AD}[49,50]$. These findings suggest that prior to extracellular $A \beta$ deposition there is an accumulation of intracellular $A \beta$ within neurons in DS at a much earlier age than in the general population. Thus, intracellular $A \beta$ accumulation may be important in the developmental course of DS and occurs prior to and contributes to age-associated extracellular $A \beta$ deposition. The accumulation of neuronal $A \beta$ may be associated with caspase cleavage products leading to increased apoptosis [51], which in turn may partially account for observed brain atrophy and neuronal loss. Intracellular $A \beta$ is localized to endosomes, intracellular organelles responsible for degrading and turning over proteins within cells $[52,53]$. Interestingly, partially reducing BACE1 in the Ts2 mouse model of DS leads to a reduction in endosomal abnormalities [54] typically oserved in the DS brain [53]

\section{A $\beta$ Plaques}

There is a well established literature that that $A \beta$ accumulates within plaques in DS in an age dependent process [10]. Cerebral A $\beta$ deposition occurs decades earlier in DS compared to $\mathrm{AD}$ and control brains [14]. The deposition of extracellular $\mathrm{A} \beta$ in diffuse plaques is consistent after the age of 30 years [55], although widespread diffuse $A \beta 42$ plaques have also been observed in brain sections from young DS individuals under 20 years of age [10, 56-58]. However, it is important to note that the early $A \beta$ deposits reported by Lemere and colleagues were from individuals who were institutionalized [56] suggesting a possible environmental impact or severity of intellectual disability in DS on A $\beta$ accumulation. It is also apparent that diffuse plaques precede neuritic plaques with age in the cortex.

In DS, $A \beta 42$ diffuse plaques precede fibrillar senile plaques containing dystrophic neurites and the formation of neurofibrillary tangles, and $\mathrm{A} \beta 42$ plaques are more prevalent than $A \beta 40$ plaques at all ages [56, 59]. Diffuse A $\beta 42$ is also deposited in DS cerebellum and striatum in the third decade of life, but fibrillar plaques are rarely observed in these brain areas in the older DS brain [60], suggesting regional effects on plaque maturation. Overall, 
senile plaques progress in the same brain regions and cortical layers as in $\mathrm{AD}$, however, plaque density is higher in DS brain [61].

Between the ages of 30 and 40 years, neuropathology accumulates until it reaches levels sufficient for a diagnosis of AD in DS by age 40 years [62]. In fact, there is an exponential rise in $A \beta$ plaques, and specifically insoluble (formic acid extracted) $A \beta$ measured biochemically after the age of 40 years [21,22], suggesting an acceleration phase to clinical and neuropathological disease development. Identifying factors engaged during this rapid $\mathrm{AD}$ pathogenesis phase in DS may provide novel targets for intervention. For example, the presence of an Apo E $\varepsilon 4$ allele doubles the cerebral amyloid plaque burden and shortens life span in DS [63].

\section{Post-translationally Modified A $\beta$}

A characteristic of $A \beta$ is that there are several amino acids that are vulnerable to posttranslational modifications and identifying these species provides a measure of biologically "older" deposits (reviewed in $[9,10]$ ). With age, extracellular A $\beta$ with the Nterminus starting at Asp1 in DS is post-translationally modified by isomerization [64], racemization [65] and oxidation [66]. Oxidized $A \beta$ may reflect abnormalities in redox homeostasis observed in DS [67] and also possibly suggests amelioration through uprgulation of vitagenes [68]. An N-terminally truncated form of $A \beta$ is generated by degradation of the first 2 amino acids followed by cyclization of the newly formed $\mathrm{N}$ terminus by glutaminyl cyclase, resulting in degradation-resistant, highly toxic aggregates of pyroglutamate-3 $\mathrm{A} \beta$ that deposit into plaques and blood vessel walls in AD and DS brain [56, 69-71]. Pyroglutamate-11 A $\beta$, a minor species, is also detected in some plaque cores and vascular amyloid in DS brain [72, 73]. Unmodified A $\beta 1-40 / 42$ is also elevated in DS brain, possibly due to the overexpression of BACE 2, a gene encoded on chromosome 21 [73]. In addition, the APP P3 peptide, starting at the non-amyloidogenic a-secretase site (A $\beta 17$ leu), can be observed readily in DS brain extracts [74] and cerebellar plaques [75]. These modifications may reflect mechanisms of $A \beta$ production and could potentially serve as possible chronobiological age markers for individual deposits and $\mathrm{AD}$ progression.

\section{Cerebrovascular A $\beta$ Pathology in DS}

The contriboution of cerebrovascular disease (CVD) to $\mathrm{AD}$ is increasingly being recognized as a critical comorbidity that accelerates the age of onset of dementia and also leads to a faster progression of the disease [76]. Further, estimates of a mixed etiology of AD that includes CVD range from 5.7-45\% of autopsy cases from the general population [77]. CVD can serve as a "second hit" necessary for clinical signs of dementia, particularly when significant $A \beta$ is present in the brain [78]. DS represents a unique opportunity to study the cerebrovascular features of aging and $\mathrm{AD}$ in the context of limited systemic vascular risk factors (reviewed in [79]) including absence of atheroma and hypertension.

Cerebral amyloid angiopathy (CAA) is the deposition of amyloid in the walls of mediumand small-size leptomeningeal and cortical arteries, arterioles and, less frequently, capillaries and veins. CAA can lead to micro and macro hemorrhages [80]. CAA is consistently 
observed in older individuals with DS (>55 yrs - [81-83] although study sizes include relatively small cohorts. CAA contains post-translationally modified $A \beta[71]$ as described in plaques. There are few reports of CAA in DS being associated with hemorrhages [83-87] in some but not all case reports [81, 82]. Brain A 340 (typically associated with CAA) rises exponentially with age in DS [21]. The functional consequences of CAA remains an area rich for futher study as adults with DS represent a unique cohort to study the consequences of CVD co-morbidities in the absence of several cardiovascular risk factors. There are currently no systematic reports of CVD as a function of aging or cognition in DS. In terms of designing future clinical trials, characterizing the age of onset and extent of CVD in adults with DS will be critical given that CVD is mediated to large extent by lifestyle factors that are amenable to intervention such asindividuals with hypertension, high cholesterol, obesity or type II diabetes (reviewed in: [88]).

\section{Enzymes involved with $A \beta$ Degradation and Clearance in the Brain and DS}

Several enzymes in the brainare involved with the degradation and clearance of $A \beta$. These $A \beta$ clearing enzymes include insulin degrading enzyme (IDE), neprilysin, and tissue plasminogen activator [89-91]. In DS, two components leading to increased production of A $\beta$ are present in triplicate and include APP and BACE2. However, despite life-long overexpression of these two proteins, full blown AD neuropathology is not consistently observed until after age 40 years. Thus, $A \beta$ may be cleared or degraded in the DS brain by the activity of these $A \beta$ degrading enzymes.

Neprilysin protein concentration is increased in DS and correlates with levels of insoluble A $\beta$ [23]. Further, the overexpression of DRYK1a in DS [92] reduces neprilysin activity in DS fibroblasts [93]. Normalization of reduced neprilysin protein levels in the Ts65Dn mouse model of DS by environmental enrichment is associated with improved cognition [41]. Considering the therapeutic potential of enhancing $A \beta$ degradation and clearance, this represents a major gap in our knowledge in the study of development and aging in DS. Studies of age-dependent changes in IDE or tissue plasminogen activator were not found suggesting this is an area requiring further study in DS.

\section{Case Studies Supporting the Role of APP and A $\beta$ in AD Pathogenesis in DS}

The most common cause of DS is trisomy 21 accounting for $95 \%$ of all individuals with DS. However, two other causes include partial trisomy 21 (4\% of people) and mosaicism (1\% of people). There are few case studies of unique individuals with DS who are mosaic or have parital trisomy and thus, have varying degrees of APP overexpression. In 1998, Prasher and colleagues described a 78 year old female with DS who did not develop dementia and who did not show autopsy evidence of AD. Molecular mapping studies determined that this person was disomic for APP and SOD1 but trisomic for S100 $\beta$ [94]. Recently, Doran and colleagues describe a second partial trisomy case, a male who lived to 72 years of age without dementia [95]. This person was negative for Pittsburgh Compound B (PiB) amyloid imaging and at autopsy, showed little A $\beta$ (sporadic plaques) and a Braak stage III. Genetic mapping of this partial trisomy case indicated that APP was present in duplicate but S100 $\beta$ 
and SOD1 were triplicated. Thus, studies of people with partial trisomy 21 strongly suggest that the presence of APP is critically involved with the development of AD.

Another fascinating case report by Ringman and colleagues describes a 55 year old man with a mild intellectual delay but early onset dementia [96]. Standard karyotyping showed that he was $10 \%$ mosaic for chromosome 21 . There have been three similar previous reports of people with mosaicism with varying degrees of a DS phenotype but all developed early onset dementia (41-52 years) [97-99]. Older people with DS also show evidence of an acquired low level mosaicism suggesting a loss of chromosome 21, the functional consequences of this observation are as yet unknown [100]. Mosaic DS case studies suggest that even a small increase in genetic APP load and possibly A $\beta$ is sufficient to drive early onset dementia in DS.

\section{$A \beta$ Neuroimaging}

There have been several reviews describing structural and functional neuroimaging outcomes in people with DS [11, 101]. For this review, we will focus on A $\beta$ neuroimaging. In vivo ligands have been developed that selectively bind to $A \beta$ and can be used in conjuction with positron emission tomography (PET) to visualize $\mathrm{A} \beta$ plaques in people antemortem [102-105]. Pittsburgh Compound B (PiB) [106], the first of these A $\beta$ ligands, has now been used in a large number of clinical studies in patients with AD and can detect $\mathrm{A} \beta$ load early in the disease [103].

In DS, PiB PET imaging studies indicate that binding is age-dependent [107-111](Figure 3). In people with DS who are cognitively impaired, there is a positive correlation with the extent of PiB binding [107, 110]. Interestingly, the striatum is the earliest site of PiB binding in DS, typically observed after 35 years of age [107-109]. This finding is similar to reports of patients with presenilin-1 mutations [112-114]. With age, more brain regions, primarily cortical, show in vivo $\mathrm{A} \beta$ binding [107].

Similar results have been reported for other A $\beta$ ligands including Florbetapir [115-117] and 2-(1-[118] ethylidene) malononitrile ([(18)F]FDDNP) [118]. FDDNP also binds to tau and it is not possible to distinguish $\mathrm{A} \beta$ plaques from neurofibrillary tangles. It is interesting to note, however, that florbeptir and FDDNP do not show early striatal binding as reported for $\mathrm{PiB}$, suggesting that either the various ligands have different affinity for different types of $\mathrm{A} \beta$ or that PiB binding may also indicate additional neuropathologies.

A recent report of 3 years of longitudinal study of $\mathrm{PiB}$ binding in nondemented people with DS showed that $85 \%$ of $\mathrm{PiB}$ negative subjects remained negative while $15 \%$ converted to being PiB positive [119]. Those who converted to being PiB positive tended to show a $3.7 \%$ increase in binding per year. (Figure 4)

\section{PiB in DS - autopsy studies}

In vivo imaging using $\mathrm{PiB}$ suggests that cortical binding is age dependent. In autopsy cases with sporadic $\mathrm{AD},{ }^{3} \mathrm{H}-\mathrm{PiB}$ and $6-\mathrm{CN}-\mathrm{PiB}$ binding in vitro has been described $[112,120$ 123]. In these studies, $P i B$ binds to $A \beta 40$ and $A \beta 42$ positive plaques as well as vascular $A \beta$. 
Further, $\mathrm{PiB}$ binding was more robust in compact or cored plaques and less so with diffuse plaques. PiB binding also correlates with insoluble $A \beta$ measures and with plaque loads. In one case that was PET imaged in life with PiB and then came to autopsy, there was a significant overlap in the regional distribution of the in vivo plaque binding and in vitro $\mathrm{PiB}$ binding [122].

A recent study described PiB binding in vitro in DS brain [124]. Biochemical measures of $\mathrm{PiB}$ binding in vitro using ${ }^{3} \mathrm{H}-\mathrm{PiB}$ was significantly associated with increasing age. After age 40 years in DS, ${ }^{3} \mathrm{H}-\mathrm{PiB}$ binding rose dramatically along with increasing individual variability. ${ }^{3} \mathrm{H}-\mathrm{PiB}$ binding correlated with the amount of $\mathrm{A} \beta 42$. Frontal cortex neuritic and cored plaques in DS brain along with extensive cerebral amyloid angiopathy (CAA) were positive for 6-CN-PiB. Thus, cortical PiB binding in vivo as shown by PET imaging reflects plaques and CAA in DS brain (Figure 5).

\section{Summary}

People with DS show age-dependent accumulations of $A \beta$ in plaques and in CAA similar to that observed in sporadic AD. However, the age of onset of $A \beta$ appears to be at least a decade if not more, earlier than that reported for the general population. The age-depedency of $A \beta$ accumulation provides unique opportunities for targeted clinical trials in people with DS to slow or prevent AD as prophylactic windows can be identified based on plasma, neuroimaging, and clinical markers of $\mathrm{AD}$ processes. However, there are still several gaps remaining in our understanding of $A \beta$ accumulation in DS including a lack of information regarding Braak amyloid staging and severity of dementia as well as the need to learn more about PiB binding in striatum (along with functional consequences). Autopsy studies in people with DS are challenging and the amount of tissue available for research from clinically characterized and prospectively followed people is very limited. New ligands that bind to tau pathology are currently being examined in DS cohorts and will provide novel and exciting information as to the staging of $\mathrm{A} \beta$ vs tau with age and links to cognition.

\section{Acknowledgments}

Funding: This work was supported by the National Institutes of Health through the National Institutes on Child Health and Development (grant \#R01HD064993).

\section{References}

1. Glasson EJ, Sullivan SG, Hussain R, Petterson BA, Montgomery PD, Bittles AH. The changing survival profile of people with Down's syndrome: implications for genetic counselling. Clinical genetics. 2002; 62(5):390-3. [PubMed: 12431254]

2. Bittles AH, Bower C, Hussain R, Glasson EJ. The four ages of Down syndrome. Eur J Public Health. 2007; 17(2):221-5. [PubMed: 16857692]

3. Wu J, Morris JK. The population prevalence of Down's syndrome in England and Wales in 2011, European journal of human genetics. EJHG. 2013; 21(9):1016-9. [PubMed: 23321618]

4. Hippius H, Neundorfer G. The discovery of Alzheimer's disease. Dialogues in clinical neuroscience. 2003; 5(1):101-8. [PubMed: 22034141]

5. Hardy J. Alzheimer's disease: the amyloid cascade hypothesis: an update and reappraisal. J Alzheimers Dis. 2006; 9(3 Suppl):151-3. [PubMed: 16914853] 
6. Hardy JA, Higgins GA. Alzheimer's disease: the amyloid cascade hypothesis. Science. 1992; 256(5054):184-5. [PubMed: 1566067]

7. Farlow MR, Brosch JR. Immunotherapy for Alzheimer's disease. Neurol Clin. 2013; 31(3):869-78. [PubMed: 23896510]

8. Becker RE, Greig NH. Alzheimer's disease drug development in 2008 and beyond: problems and opportunities. Curr Alzheimer Res. 2008; 5(4):346-57. [PubMed: 18690832]

9. Head E, Lott IT. Down syndrome and beta-amyloid deposition. Curr Opin Neurol. 2004; 17(2):95100. [PubMed: 15021233]

10. Head E, Lott IT, Wilcock DM, Lemere CA. Aging in Down Syndrome and the Development of Alzheimer's Disease Neuropathology. Curr Alzheimer Res. 2016; 13(1):18-29. [PubMed: 26651341]

11. Head E, Powell D, Gold BT, Schmitt FA. Alzheimer's disease in Down syndrome. European Journal of Neurodegenerative Diseases. 2012; 1(3):353-364.

12. Nunan J, Small DH. Regulation of APP cleavage by a-, b- and g-secretases. FEBS Letters. 2000; 483:6-10. [PubMed: 11033346]

13. Selkoe DJ. Normal and abnormal biology of the beta-amyloid precursor protein. Annu Rev Neurosci. 1994; 17:489-517. [PubMed: 8210185]

14. Rumble B, Retallack R, Hilbich C, Simms G, Multhaup G, Martins R, Hockey A, Montgomery P, Beyreuther K, Masters CL. Amyloid A4 and its precursor in Down's syndrome and Alzheimer's disease. New Engl J Med. 1989; 320:1446-1462. [PubMed: 2566117]

15. Tanzi RE, McClatchey AI, Lamperti ED, Villa-komaroff L, Gusella JF, Neve RL. Protease inhibitor domain encoded by an amyloid protein precursor mRNA associated with Alzheimer's diase. Nature. 1988; 333:528-530.

16. Glenner GG, Wong CW. Alzheimer's disease and Down's syndrome sharing of a unique cerebrovascular amyloid fibril protein. Biochem Biophys Res Commun. 1984; 120:885-890. [PubMed: 6375662]

17. Masters CL, Simms G, Weinman NA, Multhaup G, McDonald BL, Beyreuther K. Amyloid plaque core protein in Alzheimer disease and Down syndrome. Proceedings of the National Academy of Sciences of the United States of America. 1985; 82:4245-4249. [PubMed: 3159021]

18. Vassar R, Bennett BD, Babu-Khan S, Kahn S, Mendiaz EA, Denis P, Teplow DB, Ross S, Amarante P, Loeloff R, Luo Y, Fisher S, Fuller J, Edenson S, Lile J, Jarosinski MA, Biere AL, Curran E, Burgess T, Louis JC, Collins F, Treanor J, Rogers G, Citron M. Beta-secretase cleavage of Alzheimer's amyloid precursor protein by the transmembrane aspartic protease BACE. Science. 1999; 286(5440):735-41. [PubMed: 10531052]

19. Kimberly WT, LaVoie MJ, Ostaszewski BL, Ye W, Wolfe MS, Selkoe DJ. Gamma-secretase is a membrane protein complex comprised of presenilin, nicastrin, Aph-1, and Pen-2. Proc Natl Acad Sci U S A. 2003; 100(11):6382-7. [PubMed: 12740439]

20. Teller JK, Russo C, DeBusk LM, Angelini G, Zacceo D, Dagna-Bricarelli F, Scartezzini P, Bertolini F, Mann DMA, Tabaton M, Gambetti P. Presence of soluble amyloid b-peptide precedes amyloid plaque formation in Down's syndrome. Nature Medicine. 1996; 2(1):93-95.

21. Cenini G, Dowling AL, Beckett TL, Barone E, Mancuso C, Murphy MP, Levine H 3rd, Lott IT, Schmitt FA, Butterfield DA, Head E. Association between frontal cortex oxidative damage and beta-amyloid as a function of age in Down syndrome. Biochim Biophys Acta. 2012; 1822(2):130 8. [PubMed: 22009041]

22. Nistor M, Don M, Parekh M, Sarsoza F, Goodus M, Lopez GE, Kawas C, Leverenz J, Doran E, Lott IT, Hill M, Head E. Alpha- and beta-secretase activity as a function of age and beta-amyloid in Down syndrome and normal brain. Neurobiol Aging. 2007; 28(10):1493-506. [PubMed: 16904243]

23. Miners JS, Morris S, Love S, Kehoe PG. Accumulation of insoluble amyloid-beta in down's syndrome is associated with increased BACE-1 and neprilysin activities. J Alzheimers Dis. 2011; 23(1):101-8. [PubMed: 20930275]

24. Holler CJ, Webb RL, Laux AL, Beckett TL, Niedowicz DM, Ahmed RR, Liu Y, Simmons CR, Dowling AL, Spinelli A, Khurgel M, Estus S, Head E, Hersh LB, Murphy MP. BACE2 expression 
increases in human neurodegenerative disease. Am J Pathol. 2012; 180(1):337-50. [PubMed: 22074738]

25. Webb RL, Murphy MP. beta-Secretases, Alzheimer's Disease, and Down Syndrome. Curr Gerontol Geriatr Res. 2012; 2012:362839. [PubMed: 22481915]

26. Hussain I, Powell DJ, Howlett DR, Chapman GA, Gilmour L, Murdock PR, Tew DG, Meek TD, Chapman C, Schneider K, Ratcliffe SJ, Tattersall D, Testa TT, Southan C, Ryan DM, Simmons DL, Walsh FS, Dingwall C, Christie G. ASP1 (BACE2) cleaves the amyloid precursor protein at the beta-secretase site. Mol Cell Neurosci. 2000; 16(5):609-19. [PubMed: 11083922]

27. Barbiero L, Benussi L, Ghidoni R, Alberici A, Russo C, Schettini G, Pagano SF, Parati EA, Mazzoli F, Nicosia F, Signorini S, Feudatari E, Binetti G. BACE-2 is overexpressed in Down's syndrome. Exp Neurol. 2003; 182:335-345. [PubMed: 12895444]

28. Motonaga K, Itoh M, Becker LE, Goto Y, Takashima S. Elevated expression of beta-site amyloid precursor protein cleaving enzyme 2 in brains of patients with Down syndrome. Neurosci Lett. 2002; 326:64-66. [PubMed: 12052539]

29. Cheon MS, Dierssen M, Kim SH, Lubec G. Protein expression of BACE1, BACE2 and APP in Down syndrome brains. Amino Acids. 2008; 35(2):339-43. [PubMed: 18163181]

30. Walsh DM, Klyubin I, Fadeeva JV, Rowan MJ, Selkoe DJ. Amyloid-beta oligomers: their production, toxicity and therapeutic inhibition. Biochem Soc Trans. 2002; 30(4):552-7. [PubMed: 12196135]

31. Lambert MP, Barlow AK, Chromy BA, Edwards C, Freed R, Liosatos M, Morgan TE, Rozovsky I, Trommer B, Viola KL, Wals P, Zhang C, Finch CE, Krafft GA, Klein WL. Diffusable, nonfibrillar ligands derived from Ab1-42 are potent central nervous system neurotoxins. PNAS. 1998; 95:6448-6453. [PubMed: 9600986]

32. Walsh DM, Klyubin I, Fadeeva JV, Cullen WK, Anwyl R, Wolfe MS, Rowan MJ, Selkoe DJ. Naturally secreted oligomers of amyloid beta protein potently inhibit hippocampal long-term potentiation in vivo. Nature. 2002; 416(6880):535-9. [PubMed: 11932745]

33. Kuo YM, Emmerling MR, Vigo-Pelfrey C, Kasunic TC, Kirkpatrick JB, Murdoch GH, Ball MJ, Roher AE. Water-soluble Ab(N-40, N-42) oligomers in normal and Alzheimer disease brains. Journal of Biological Chemistry. 1996; 271:4077-4081. [PubMed: 8626743]

34. Kayed R, Head E, Thompson JL, McIntire TM, Milton SC, Cotman CW, Glabe CG. Common structure of soluble amyloid oligomers implies common mechanism of pathogenesis. Science. 2003; 300:486-489. [PubMed: 12702875]

35. Gong Y, Chang L, Viola KL, Lacor PN, Lambert MP, Finch CE, Krafft GA, Klein WL. Alzheimer's disease-affected brain: Presence of oligomeric Ab ligands (ADDLs) suggests a molecular basis for reversible memory loss. PNAS. 2003; 100(18):10417-10422. [PubMed: 12925731]

36. Di Domenico F, Coccia R, Cocciolo A, Murphy MP, Cenini G, Head E, Butterfield DA, Giorgi A, Schinina ME, Mancuso C, Cini C, Perluigi M. Impairment of proteostasis network in Down syndrome prior to the development of Alzheimer's disease neuropathology: redox proteomics analysis of human brain. Biochim Biophys Acta. 2013; 1832(8):1249-59. [PubMed: 23603808]

37. Ji L, Chauhan V, Mehta P, Wegiel J, Mehta S, Chauhan A. Relationship between proteolytically cleaved gelsolin and levels of amyloid-beta protein in the brains of Down syndrome subjects. J Alzheimers Dis. 2010; 22(2):609-17. [PubMed: 20847428]

38. Russo C, Saido TC, DeBusk LM, Tabaton M, Gambetti P, Teller JK. Heterogeneity of watersoluble amyloid beta-peptide in Alzheimer's disease and Down's syndrome brains. FEBS Lett. 1997; 409(3):411-6. [PubMed: 9224700]

39. Martin SB, Dowling AL, Lianekhammy J, Lott IT, Doran E, Murphy MP, Beckett TL, Schmitt FA, Head E. Synaptophysin and Synaptojanin-1 in Down Syndrome are Differentially Affected by Alzheimer's Disease. J Alzheimers Dis. 2014

40. Sarsoza F, Saing T, Kayed R, Dahlin R, Dick M, Broadwater-Hollifield C, Mobley S, Lott I, Doran E, Gillen D, Anderson-Bergman C, Cribbs DH, Glabe C, Head E. A fibril-specific, conformationdependent antibody recognizes a subset of Abeta plaques in Alzheimer disease, Down syndrome and Tg2576 transgenic mouse brain. Acta Neuropathol. 2009 
41. Sansevero G, Begenisic T, Mainardi M, Sale A. Experience-dependent reduction of soluble betaamyloid oligomers and rescue of cognitive abilities in middle-age Ts65Dn mice, a model of Down syndrome. Exp Neurol. 2016; 283(Pt A):49-56. [PubMed: 27288239]

42. Cuello AC, Allard S, Ferretti MT. Evidence for the accumulation of Abeta immunoreactive material in the human brain and in transgenic animal models. Life Sci. 2012; 91(23-24):1141-7. [PubMed: 22705309]

43. Gyure KA, Durham R, Stewart WF, Smialek JE, Troncoso JC. Intraneuronal Ab -Amyloid precedes development of amyloid plaques in Down syndrome. Arch Pathol Lab Med. 2001; 125:489-492. [PubMed: 11260621]

44. Mori C, Spooner ET, Wisniewsk KE, Wisniewski TM, Yamaguch H, Saido TC, Tolan DR, Selkoe DJ, Lemere CA. Intraneuronal Abeta42 accumulation in Down syndrome brain. Amyloid. 2002; 9(2):88-102. [PubMed: 12440481]

45. Gouras GK, Tsai J, Naslund J, Vincent B, Edgar M, Checler F, Greenfield JP, Haroutunian V, Buxbaum JD, Xu H, Greengard P, Relkin NR. Intraneuronal Abeta42 accumulation in human brain. Am J Pathol. 2000; 156(1):15-20. [PubMed: 10623648]

46. Hirayama A, Horikoshi Y, Maeda M, Ito M, Takashima S. Characteristic developmental expression of amyloid b40,42 and 43 in patients with Down syndrome. Brain \& Development. 2003; 25:180 185. [PubMed: 12689696]

47. Knauer MF, Soreghan B, Burdick D, Kosmoski J, Glabe CG. Intracellular accumulation and resistance to degradation of the Alzheimer amyloid A4/beta protein. Proc Natl Acad Sci U S A. 1992; 89(16):7437-41. [PubMed: 1502155]

48. Yang AJ, Chandswangbhuvana D, Shu T, Henschen A, Glabe CG. Intracellular accumulation of insoluble, newly synthesized abetan-42 in amyloid precursor protein-transfected cells that have been treated with Abeta1-42. J Biol Chem. 1999; 274(29):20650-6. [PubMed: 10400697]

49. Oddo S, Caccamo A, Shepherd JD, Murphy MP, Golde TE, Kayed R, Metherate R, Mattson MP, Akbari Y, LaFerla FM. Triple-transgenic model of Alzheimer's disease with plaques and tangles: Intracellular Ab and synaptic dysfunction. Neuron. 2003; 39:409-421. [PubMed: 12895417]

50. Wirth O, Multhaup G, Czech C, Blanchard V, Moussaoui S, Tremp G, Pradier L, Beyreuther K, Bayer TA. Intraneuronal $\mathrm{Ab}$ accumulation precedes plaque formation in b-amyloid precursor protein and presenilin-1 double-transgenic mice. Neurosci Lett. 2001; 306:116-120. [PubMed: 11403971]

51. Head E, Lott IT, Cribbs DH, Cotman CW, Rohn TT. Beta-amyloid deposition and neurofibrillary tangle association with caspase activation in Down syndrome. Neurosci Lett. 2002; 330(1):99_ 103. [PubMed: 12213643]

52. Cataldo AM, Peterhoff CM, Troncoso JC, Gomez-Isla T, Hyman BT, Nixon RA. Endocytic pathway abnormalities precede amyloid beta deposition in sporadic Alzheimer's disease and Down syndrome: differential effects of APOE genotype and presenilin mutations. Am J Pathol. 2000; 157:277-286. [PubMed: 10880397]

53. Cataldo AM, Petanceska S, Terio NB, Peterhoff CM, Durham R, Mercken M, Mehta PD, Buxbaum J, Haroutunian V, Nixon RA. Abeta localization in abnormal endosomes: association with earliest Abeta elevations in AD and Down syndrome. Neurobiol Aging. 2004; 25(10):1263-72. [PubMed: 15465622]

54. Jiang Y, Rigoglioso A, Peterhoff CM, Pawlik M, Sato Y, Bleiwas C, Stavrides P, Smiley JF, Ginsberg SD, Mathews PM, Levy E, Nixon RA. Partial BACE1 reduction in a Down syndrome mouse model blocks Alzheimer-related endosomal anomalies and cholinergic neurodegeneration: role of APP-CTF. Neurobiol Aging. 2016; 39:90-8. [PubMed: 26923405]

55. Mann DMA, Esiri MM. The pattern of acquisition of plaques and tangles in the brains of patients under 50 years of age with Down's syndrome. J Neurol Sci. 1989; 89:169-179. [PubMed: 2522541]

56. Lemere CA, Blusztajn JK, Yamaguchi H, Wisniewski T, Saido TC, Selkoe DJ. Sequence of deposition of heterogeneous amyloid beta-peptides and APOE in Down Syndrome: Implications for initial events in amyloid plaque formation. Neurobiology of Disease. 1996; 3:16-32. [PubMed: 9173910] 
57. Stoltzner SE, Grenfell TJ, Mori C, Wisniewski KE, Wisniewski TM, Selkoe DJ, Lemere CA. Temporal accrual of complement proteins in amyloid plaques in Down's syndrome with Alzheimer's disease. American Journal of Pathology. 2000; 156(2):489-499. [PubMed: 10666378]

58. Leverenz JB, Raskind MA. Early amyloid deposition in the medial temporal lobe of young Down syndrome patients: a regional quantitative analysis. Experimental neurology. 1998; 150(2):296304. [PubMed: 9527899]

59. Iwatsubo T, Mann DM, Odaka A, Suzuki N, Ihara Y. Amyloid beta protein (A beta) deposition: A beta 42(43) precedes A beta 40 in Down syndrome. Ann Neurol. 1995; 37(3):294-9. [PubMed: 7695229]

60. Mann DM, Iwatsubo T. Diffuse plaques in the cerebellum and corpus striatum in Down's syndrome contain amyloid beta protein (A beta) only in the form of A beta 42(43). Neurodegeneration. 1996; 5(2):115-20. [PubMed: 8819131]

61. Hof PR, Bouras C, Perl DP, Sparks DL, Mehta N, Morrison JH. Age-related distribution of neuropathologic changes in the cerebral cortex of patients with Down's syndrome. Arch Neurol. 1995; 52:379-391. [PubMed: 7710374]

62. Wisniewski K, Wisniewski H, Wen G. Occurrence of neuropathological changes and dementia of Alzheimer's disease in Down's syndrome. Ann Neurol. 1985; 17:278-282. [PubMed: 3158266]

63. Hyman BT, West HL, Rebeck GW, Lai F, Mann DM. Neuropathological changes in Down's syndrome hippocampal formation. Effect of age and apolipoprotein E genotype. Arch NeurolChicago. 1995; 52:373-378. [PubMed: 7710373]

64. Fonseca MI, Head E, Velazquez P, Cotman CW, Tenner AJ. The presence of isoaspartic acid in beta-amyloid plaques indicates plaque age. Exp Neurol. 1999; 157(2):277-88. [PubMed: 10364440]

65. Azizeh BY, Head E, Ibrahim MA, Torp R, Tenner AJ, Kim RC, Lott IT, Cotman CW. Molecular dating of senile plaques in the brains of individuals with Down syndrome and in aged dogs. Exp Neurol. 2000; 163(1):111-22. [PubMed: 10785449]

66. Head E, Garzon-Rodriguez W, Johnson JK, Lott IT, Cotman CW, Glabe C. Oxidation of Abeta and plaque biogenesis in Alzheimer's disease and Down syndrome. Neurobiol Dis. 2001; 8(5):792806. [PubMed: 11592849]

67. Barone E, Arena A, Head E, Butterfield DA, Perluigi M. Disturbance of redox homeostasis in Down Syndrome: Role of iron dysmetabolism. Free Radic Biol Med. 2017

68. Calabrese V, Giordano J, Signorile A, Laura Ontario M, Castorina S, De Pasquale C, Eckert G, Calabrese EJ. Major pathogenic mechanisms in vascular dementia: Roles of cellular stress response and hormesis in neuroprotection. J Neurosci Res. 2016; 94(12):1588-1603. [PubMed: 27662637]

69. Saido TC, Iwatsubo T, Mann DM, Shimada H, Ihara Y, Kawashima S. Dominant and differential deposition of distinct beta-amyloid peptide species, A beta N3 (pE), in senile plaques. Neuron. 1995; 14:457. [PubMed: 7857653]

70. Schilling S, Hoffmann T, Manhart S, Hoffmann M, Demuth HU. Glutaminyl cyclases unfold glutamyl cyclase activity under mild acid conditions. FEBS Lett. 2004; 563(1-3):191-6. [PubMed: 15063747]

71. Frost JL, Le KX, Cynis H, Ekpo E, Kleinschmidt M, Palmour RM, Ervin FR, Snigdha S, Cotman CW, Saido TC, Vassar RJ, St George-Hyslop P, Ikezu T, Schilling S, Demuth HU, Lemere CA. Pyroglutamate- 3 amyloid-beta deposition in the brains of humans, non-human primates, canines, and Alzheimer disease-like transgenic mouse models. Am J Pathol. 2013; 183(2):369-81. [PubMed: 23747948]

72. Iwatsubo T, Saido TC, Mann DM, Lee VM, Trojanowski JQ. Full-length amyloid-beta (1-42(43)) and amino-terminally modified and truncated amyloid-beta 42(43) deposit in diffuse plaques. Am J Pathol. 1996; 149(6):1823-30. [PubMed: 8952519]

73. Liu K, Solano I, Mann D, Lemere C, Mercken M, Trojanowski JQ, Lee VM. Characterization of Abeta11-40/42 peptide deposition in Alzheimer's disease and young Down's syndrome brains: implication of N-terminally truncated Abeta species in the pathogenesis of Alzheimer's disease. Acta Neuropathol. 2006; 112(2):163-74. [PubMed: 16865398] 
74. Saido TC, Yamao-Harigaya W, Iwatsubo T, Kawashima S. Amino- and carboxyl-terminal heterogeneity of b-amyloid peptides deposited in human brain. Neurosci Lett. 1996; 215:173-176. [PubMed: 8899741]

75. Lalowski M, Golabek A, Lemere CA, Selkoe DJ, Wisniewski HM, Beavis RC, Frangione B, Wisniewski T. The "nonamyloidogenic" p3 fragment (amyloid beta17-42) is a major constituent of Down's syndrome cerebellar preamyloid. J Biol Chem. 1996; 271(52):33623-31. [PubMed: 8969231]

76. Snyder HM, Corriveau RA, Craft S, Faber JE, Greenberg SM, Knopman D, Lamb BT, Montine TJ, Nedergaard M, Schaffer CB, Schneider JA, Wellington CL, Wilcock DM, Zipfel GJ, Zlokovic B, Bain LJ, Bosetti F, Gallis ZS, Koroshetz W, Carrillo MC. Vascular contributions to cognitive impairment and dementia including Alzheimer's disease. Alzheimers Dement. 2014

77. Jellinger KA. Pathology and pathogenesis of vascular cognitive impairment-a critical update. Frontiers in aging neuroscience. 2013; 5:17. [PubMed: 23596414]

78. Provenzano FA, Muraskin J, Tosto G, Narkhede A, Wasserman BT, Griffith EY, Guzman VA, Meier IB, Zimmerman ME, Brickman AM. I. Alzheimer's Disease Neuroimaging. White matter hyperintensities and cerebral amyloidosis: necessary and sufficient for clinical expression of Alzheimer disease? JAMA neurology. 2013; 70(4):455-61. [PubMed: 23420027]

79. Wilcock DM, Schmitt FA, Head E. Cerebrovascular contributions to aging and Alzheimer's disease in Down syndrome. Biochim Biophys Acta. 2015

80. Vinters HV. Cerebral amyloid angiopathy. A critical review. Stroke. 1987; 18(2):311-24. [PubMed: 3551211]

81. Ikeda S, Tokuda T, Yanagisawa N, Kametani F, Ohshima T, Allsop D. Variability of beta-amyloid protein deposited lesions in Down's syndrome brains. Tohoku J Exp Med. 1994; 174(3):189-98. [PubMed: 7761984]

82. Lai F, Williams MD. A prospective study of Alzheimer Disease in Down Syndrome. Arch NeurolChicago. 1989; 46:849-853. [PubMed: 2527024]

83. Belza MG, Urich H. Cerebral amyloid angiopathy in Down's syndrome. Clin Neuropathol. 1986; 5(6):257-60. [PubMed: 2949903]

84. Mendel T, Bertrand E, Szpak GM, Stepien T, Wierzba-Bobrowicz T. Cerebral amyloid angiopathy as a cause of an extensive brain hemorrhage in adult patient with Down's syndrome - a case report. Folia Neuropathol. 2010; 48(3):206-11. [PubMed: 20925005]

85. Naito KS, Sekijima Y, Ikeda S. Cerebral amyloid angiopathy-related hemorrhage in a middle-aged patient with Down's syndrome. Amyloid. 2008; 15(4):275-7. [PubMed: 19065301]

86. McCarron MO, Nicoll JA, Graham DI. A quartet of Down's syndrome, Alzheimer's disease, cerebral amyloid angiopathy, and cerebral haemorrhage: interacting genetic risk factors. J Neurol Neurosurg Psychiatry. 1998; 65(3):405-6. [PubMed: 9728967]

87. Donahue JE, Khurana JS, Adelman LS. Intracerebral hemorrhage in two patients with Down's syndrome and cerebral amyloid angiopathy. Acta Neuropathol. 1998; 95(2):213-6. [PubMed: 9498059]

88. Reitz C, Mayeux R. Alzheimer disease: epidemiology, diagnostic criteria, risk factors and biomarkers. Biochem Pharmacol. 2014; 88(4):640-51. [PubMed: 24398425]

89. Carson JA, Turner AJ. Beta-amyloid catabolism: roles for neprilysin (NEP) and other metallopeptidases? J Neurochem. 2002; 81(1):1-8.

90. Melchor JP, Pawlak R, Stickland S. The tissue plasminogen activator-plasminogen proteolytic cascade accelerates amyloid-b (Ab) degradation and inhibits Ab-induced neurodegeneration. $\mathbf{J}$ Neurosci. 2003; 23(26):8867-8871. [PubMed: 14523088]

91. Selkoe DJ. Clearing the brain's amyloid cobwebs. Neuron. 2001; 32:177-180. [PubMed: 11683988]

92. Dowjat WK, Adayev T, Kuchna I, Nowicki K, Palminiello S, Hwang YW, Wegiel J. Trisomydriven overexpression of DYRK1A kinase in the brain of subjects with Down syndrome. Neurosci Lett. 2007; 413(1):77-81. [PubMed: 17145134]

93. Kawakubo T, Mori R, Shirotani K, Iwata N, Asai M. Neprilysin Is Suppressed by Dual-Specificity Tyrosine-Phosphorylation Regulated Kinase 1A (DYRK1A) in Down-Syndrome-Derived Fibroblasts. Biological \& pharmaceutical bulletin. 2017; 40(3):327-333. [PubMed: 28250274] 
94. Prasher VP, Farrer MJ, Kessling AM, Fisher EM, West RJ, Barber PC, Butler AC. Molecular mapping of Alzheimer-type dementia in Down's syndrome. Ann Neurol. 1998; 43(3):380-3. [PubMed: 9506555]

95. Doran E, Keator D, Head E, Phelan MJ, Kim R, Totoiu M, Barrio JR, Small GW, Potkin SG, Lott IT. Down Syndrome, Partial Trisomy 21, and Absence of Alzheimer's Disease: The Role of APP. J Alzheimers Dis. 2017; 56(2):459-470. [PubMed: 27983553]

96. Ringman JM, Rao PN, Lu PH, Cederbaum S. Mosaicism for trisomy 21 in a patient with youngonset dementia: a case report and brief literature review. Arch Neurol. 2008; 65(3):412-5. [PubMed: 18332257]

97. Rowe IF, Ridler MA, Gibberd FB. Presenile dementia associated with mosaic trisomy 21 in a patient with a Down syndrome child. Lancet. 1989; 2(8656):229.

98. Puri BK, Zhang Z, Singh I. SPECT in adult mosaic Down's syndrome with early dementia. Clinical nuclear medicine. 1994; 19(11):989-91. [PubMed: 7842596]

99. Schapiro MB, Kumar A, White B, Grady CL, Friedland RP, Rapoport SI. Alzheimer's disease (AD) in mosaic/translocation Down's syndrome (Ds) without mental retardation. Neurology. 1989; 39(Suppl 1):169.

100. Jenkins EC, Schupf N, Genovese M, Ye LL, Kapell D, Canto B, Harris M, Devenny D, Lee JH, Brown WT. Increased low-level chromosome 21 mosaicism in older individuals with Down syndrome. Am J Med Genet. 1997; 68(2):147-51. [PubMed: 9028448]

101. Teipel SJ, Hampel H. Neuroanatomy of Down syndrome in vivo: a model of preclinical Alzheimer's disease. Behav Genet. 2006; 36(3):405-15. [PubMed: 16485178]

102. Sperling R, Mormino E, Johnson K. The evolution of preclinical Alzheimer's disease: implications for prevention trials. Neuron. 2014; 84(3):608-22. [PubMed: 25442939]

103. Cohen AD, Klunk WE. Early detection of Alzheimer's disease using PiB and FDG PET. Neurobiol Dis. 2014; 72(Pt A):117-22. [PubMed: 24825318]

104. Cohen Kadosh K, Johnson MH, Dick F, Cohen Kadosh R, Blakemore SJ. Effects of age, task performance, and structural brain development on face processing. Cereb Cortex. 2013; 23(7): 1630-42. [PubMed: 22661406]

105. Mintun MA, Larossa GN, Sheline YI, Dence CS, Lee SY, Mach RH, Klunk WE, Mathis CA, DeKosky ST, Morris JC. [11C]PIB in a nondemented population: potential antecedent marker of Alzheimer disease. Neurology. 2006; 67(3):446-52. [PubMed: 16894106]

106. Klunk WE, Engler H, Nordberg A, Wang Y, Blomqvist G, Holt DP, Bergstrom M, Savitcheva I, Huang GF, Estrada S, Ausen B, Debnath ML, Barletta J, Price JC, Sandell J, Lopresti BJ, Wall A, Koivisto P, Antoni G, Mathis CA, Langstrom B. Imaging brain amyloid in Alzheimer's disease with Pittsburgh Compound-B. Ann Neurol. 2004; 55(3):306-19. [PubMed: 14991808]

107. Annus T, Wilson LR, Hong YT, Acosta-Cabronero J, Fryer TD, Cardenas-Blanco A, Smith R, Boros I, Coles JP, Aigbirhio FI, Menon DK, Zaman SH, Nestor PJ, Holland AJ. The pattern of amyloid accumulation in the brains of adults with Down syndrome. Alzheimers Dement. 2016; 12(5):538-45. [PubMed: 26362596]

108. Lao PJ, Betthauser TJ, Hillmer AT, Price JC, Klunk WE, Mihaila I, Higgins AT, Bulova PD, Hartley SL, Hardison R, Tumuluru RV, Murali D, Mathis CA, Cohen AD, Barnhart TE, Devenny DA, Mailick MR, Johnson SC, Handen BL, Christian BT. The effects of normal aging on amyloid-beta deposition in nondemented adults with Down syndrome as imaged by carbon 11labeled Pittsburgh compound B. Alzheimers Dement. 2016; 12(4):380-90. [PubMed: 26079411]

109. Handen BL, Cohen AD, Channamalappa U, Bulova P, Cannon SA, Cohen WI, Mathis CA, Price JC, Klunk WE. Imaging brain amyloid in nondemented young adults with Down syndrome using Pittsburgh compound B. Alzheimers Dement. 2012; 8(6):496-501. [PubMed: 23102120]

110. Hartley SL, Handen BL, Devenny DA, Hardison R, Mihaila I, Price JC, Cohen AD, Klunk WE, Mailick MR, Johnson SC, Christian BT. Cognitive functioning in relation to brain amyloid-beta in healthy adults with Down syndrome. Brain. 2014; 137(Pt 9):2556-63. [PubMed: 24993958]

111. Landt J, D'Abrera JC, Holland AJ, Aigbirhio FI, Fryer TD, Canales R, Hong YT, Menon DK, Baron JC, Zaman SH. Using positron emission tomography and Carbon 11-labeled Pittsburgh Compound B to image Brain Fibrillar beta-amyloid in adults with down syndrome: safety, acceptability, and feasibility. Arch Neurol. 2011; 68(7):890-6. [PubMed: 21403005] 
112. Klunk WE, Price JC, Mathis CA, Tsopelas ND, Lopresti BJ, Ziolko SK, Bi W, Hoge JA, Cohen AD, Ikonomovic MD, Saxton JA, Snitz BE, Pollen DA, Moonis M, Lippa CF, Swearer JM, Johnson KA, Rentz DM, Fischman AJ, Aizenstein HJ, DeKosky ST. Amyloid deposition begins in the striatum of presenilin-1 mutation carriers from two unrelated pedigrees. J Neurosci. 2007; 27(23):6174-84. [PubMed: 17553989]

113. Villemagne VL, Ataka S, Mizuno T, Brooks WS, Wada Y, Kondo M, Jones G, Watanabe Y, Mulligan R, Nakagawa M, Miki T, Shimada H, O’Keefe GJ, Masters CL, Mori H, Rowe CC. High striatal amyloid beta-peptide deposition across different autosomal Alzheimer disease mutation types. Arch Neurol. 2009; 66(12):1537-44. [PubMed: 20008660]

114. Koivunen J, Verkkoniemi A, Aalto S, Paetau A, Ahonen JP, Viitanen M, Nagren K, Rokka J, Haaparanta M, Kalimo H, Rinne JO. PET amyloid ligand [11C]PIB uptake shows predominantly striatal increase in variant Alzheimer's disease. Brain. 2008; 131(Pt 7):1845-53. [PubMed: 18583368]

115. Sabbagh MN, Chen K, Rogers J, Fleisher AS, Liebsack C, Bandy D, Belden C, Protas H, Thiyyagura P, Liu X, Roontiva A, Luo J, Jacobson S, Malek-Ahmadi M, Powell J, Reiman EM. Florbetapir PET, FDG PET, and MRI in Down syndrome individuals with and without Alzheimer's dementia. Alzheimers Dement. 2015; 11(8):994-1004. [PubMed: 25849033]

116. Sabbagh MN, Fleisher A, Chen K, Rogers J, Berk C, Reiman E, Pontecorvo M, Mintun M, Skovronsky D, Jacobson SA, Sue LI, Liebsack C, Charney AS, Cole L, Belden C, Beach TG. Positron emission tomography and neuropathologic estimates of fibrillar amyloid-beta in a patient with Down syndrome and Alzheimer disease. Arch Neurol. 2011; 68(11):1461-6. [PubMed: 22084131]

117. Rafii MS, Wishnek H, Brewer JB, Donohue MC, Ness S, Mobley WC, Aisen PS, Rissman RA. The down syndrome biomarker initiative (DSBI) pilot: proof of concept for deep phenotyping of Alzheimer's disease biomarkers in down syndrome. Frontiers in behavioral neuroscience. 2015; 9:239. [PubMed: 26441570]

118. Nelson LD, Siddarth P, Kepe V, Scheibel KE, Huang SC, Barrio JR, Small GW. Positron emission tomography of brain beta-amyloid and tau levels in adults with Down syndrome. Arch Neurol. 2011; 68(6):768-74. [PubMed: 21670401]

119. Lao PJ, Handen BL, Betthauser TJ, Mihaila I, Hartley SL, Cohen AD, Tudorascu DL, Bulova PD, Lopresti BJ, Tumuluru RV, Murali D, Mathis CA, Barnhart TE, Stone CK, Price JC, Devenny DA, Mailick MR, Klunk WE, Johnson SC, Christian BT. Longitudinal changes in amyloid positron emission tomography and volumetric magnetic resonance imaging in the nondemented Down syndrome population. Alzheimer's \& dementia. 2017; 9:1-9.

120. Ikonomovic MD, Abrahamson EE, Price JC, Hamilton RL, Mathis CA, Paljug WR, Debnath ML, Cohen AD, Mizukami K, DeKosky ST, Lopez OL, Klunk WE. Early AD pathology in a [C-11]PiB-negative case: a PiB-amyloid imaging, biochemical, and immunohistochemical study. Acta Neuropathol. 2012; 123(3):433-47. [PubMed: 22271153]

121. Ikonomovic MD, Klunk WE, Abrahamson EE, Mathis CA, Price JC, Tsopelas ND, Lopresti BJ, Ziolko S, Bi W, Paljug WR, Debnath ML, Hope CE, Isanski BA, Hamilton RL, DeKosky ST. Post-mortem correlates of in vivo PiB-PET amyloid imaging in a typical case of Alzheimer's disease. Brain. 2008; 131(Pt 6):1630-45. [PubMed: 18339640]

122. Bacskai BJ, Frosch MP, Freeman SH, Raymond SB, Augustinack JC, Johnson KA, Irizarry MC, Klunk WE, Mathis CA, Dekosky ST, Greenberg SM, Hyman BT, Growdon JH. Molecular imaging with Pittsburgh Compound B confirmed at autopsy: a case report. Arch Neurol. 2007; 64(3):431-4. [PubMed: 17353389]

123. Beckett TL, Webb RL, Niedowicz DM, Holler CJ, Matveev S, Baig I, LeVine H 3rd, Keller JN, Murphy MP. Postmortem Pittsburgh Compound B (PiB) binding increases with Alzheimer's disease progression. J Alzheimers Dis. 2012; 32(1):127-38. [PubMed: 22766739]

124. LeVine H 3rd, Spielmann HP, Matveev S, Cauvi FM, Murphy MP, Beckett TL, McCarty K, Lott IT, Doran E, Schmitt F, Head E. Down syndrome: age-dependence of PiB binding in postmortem frontal cortex across the lifespan. Neurobiol Aging. 2017; 54:163-169. [PubMed: 28385551]

125. Nicolas M, Hassan BA. Amyloid precursor protein and neural development. Development. 2014; 141(13):2543-8. [PubMed: 24961795] 
126. LaFerla FM, Green KN, Oddo S. Intracellular amyloid-beta in Alzheimer's disease. Nat Rev Neurosci. 2007; 8(7):499-509. [PubMed: 17551515] 


\section{Highlights}

- $\quad$ Aging in DS is associated with early onset Alzheimer disease

- Beta-amyloid increases exponentially after 40 years of age

- $\quad$ Evidence from partial trisomy DS indicates overexpression of APP leads to

$\mathrm{AD}$

- $\quad \mathrm{PiB}$ binding in DS is observed in striatum prior to cortex 


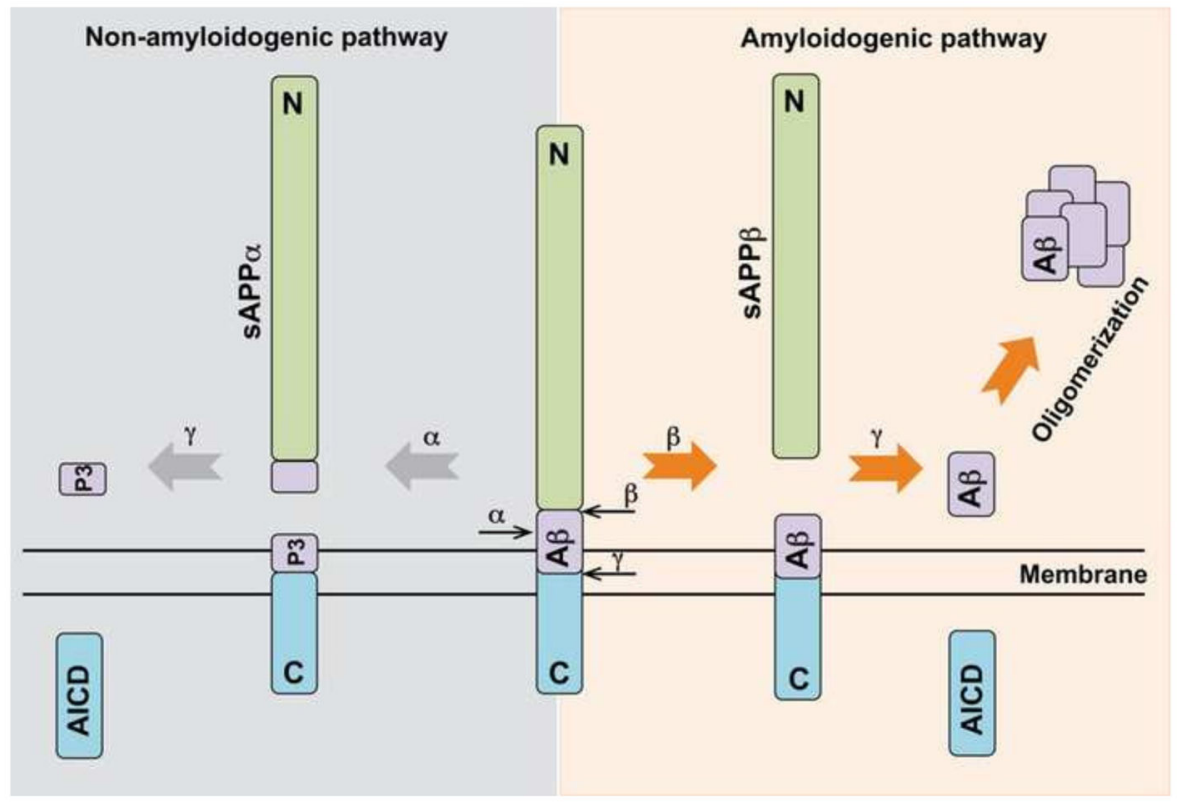

Figure 1. The proteolytic processing of APP

APP can be cleaved by $a-, \beta$ - and $\gamma$-secretases; the cleavage sites of these proteases are indicated in the full-length APP shown in the center of the figure. APP can undergo amyloidogenic (right) or non-amyloidogenic (left) processing. In the amyloidogenic pathway, cleavage by $\beta$-secretase results in the formation of soluble APP $\beta$ (sAPP $\beta$ ) and $\beta$ APP-CTF. The subsequent action of $\gamma$-secretase on $\beta$ APP-CTF releases A $\beta$ from the amyloid precursor protein intracellular domain (AICD). In the non-amyloidogenic pathway, cleavage by $a$-secretase prevents the formation of $A \beta$; $a$-secretase cleaves within the $A \beta$ sequence, giving rise to SAPPa and the membrane-tethered aAPP-CT, which in turn is cleaved by $\gamma$-secretase resulting in release of the P3 peptide and AICD. Reproduced with permission from Nicolas \& Hassan, 2014[125]. 


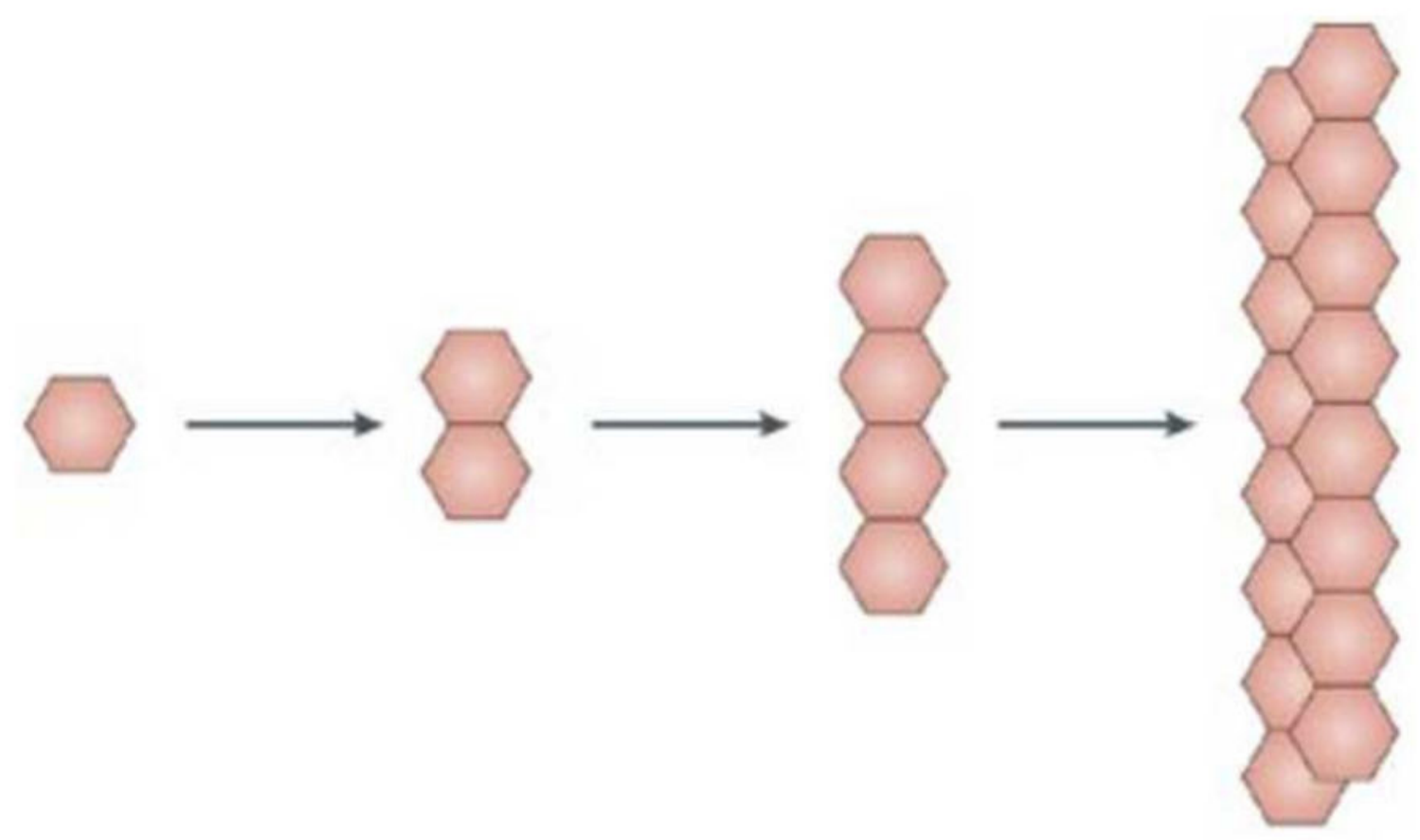

A $\beta \quad$ Oligomers

Protofibrils

Fibrils

Nature Reviews | Neuroscience

Figure 2. Oligomer pathway

Amyloid- (A) can exist in multiple assembly states - monomers, oligomers, protofibrils and fibrils - and it is the ability of this peptide to form fibrils and other intermediate states that impart the unique pathophysiological characteristics that define Alzheimer's disease pathology. Fibril formation is a complex, nucleation-dependent process. The mechanism driving this process, particularly in the elderly brain, is not yet known, but it appears to be closely related to protein misfolding. In its monomeric state, A does not appear to be neurotoxic. By contrast, oligomeric and protofibrillar species are considered potent blockers of long-term potentiation, a form of synaptic plasticity. Reproduced with permission from LaFerla and colleagues [126]. 

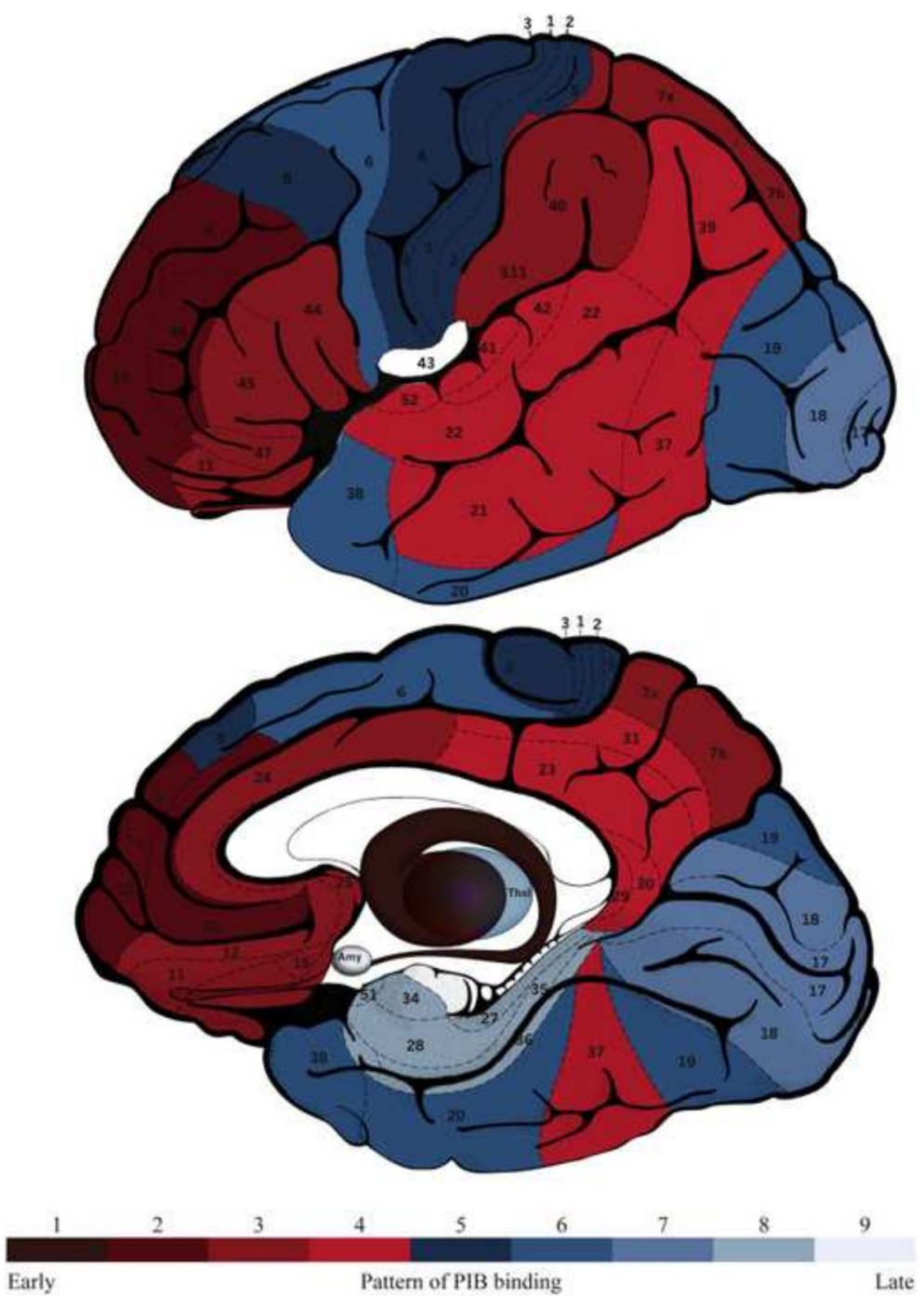

Figure 3. PiB binding in DS

A schematic brain map of numbered Brodmann areas and subcortical regions of interest colored according to the PIB staging model, where shade 1 denotes the area affected first (i.e. the striatum) and shade 9 the area affected latest (the amygdala). Abbreviations: thal, thalamus; amy, amygdala; PIB, Pittsburgh compound-B. Reproduced from Annus et al., 2016 (Creative Commons Attribution License (CC BY)[107]. 

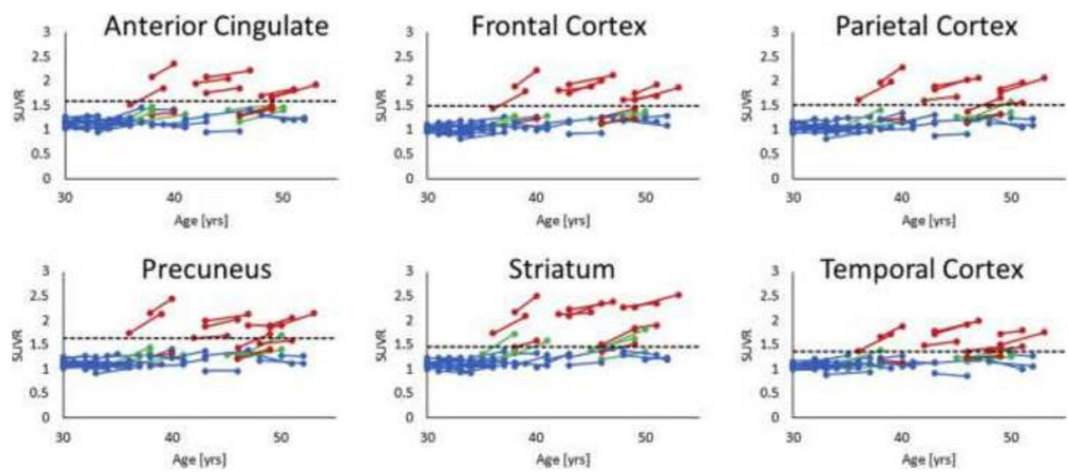

Figure 4. Longitudinal plots of mean PiB SUVR against age with the PiB positivity thresholds in each ROI shown as the dotted line. Each line represents a nondemented adult with DS. The $\mathrm{PiB}(-)$ group $(N=35)$ is shown in blue, the PiB converter group $(N=6)$ is shown in green, and the $\mathrm{PiB}(+)$ group $(N=11)$ is shown in red.

Abbreviations: PiB, Pittsburgh compound B; ROI, region of interest; SUVR, standard uptake value ratio. Reproduced from Lao et al., 2017(open access article CC BY-NC-ND)[119]. 

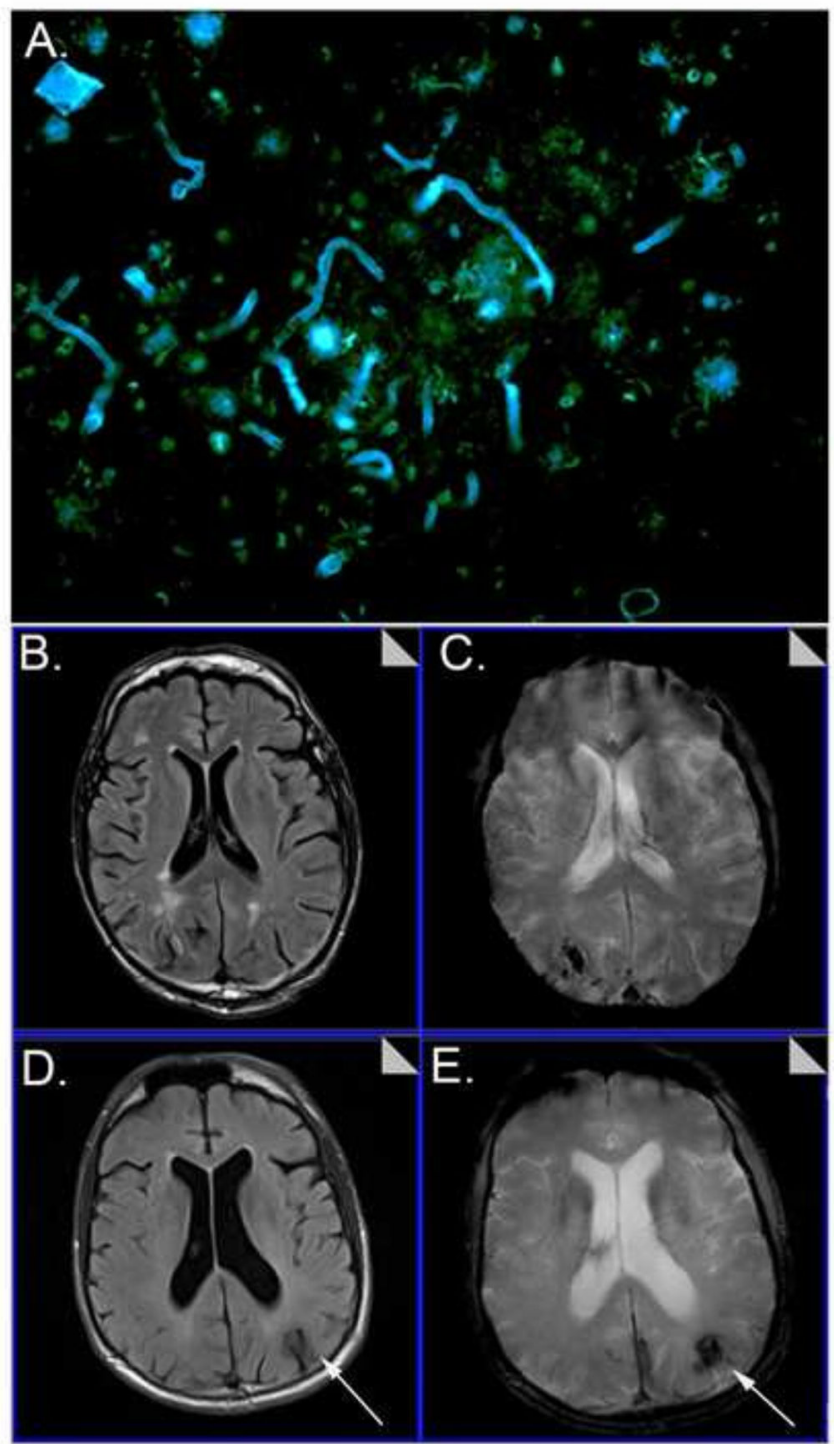

Figure 5. PiB binding to CAA and vascular pathology in DS

(A) 6-CN-PiB (blue) binds to $\mathrm{CAA}$ and to plaques (green thioflavine $\mathrm{S}$ staining) in the brain of a 41 year old female with DS and AD. CVD in two DS volunteers in the University of Kentucky aging study, 57 and 59 year old males imaged with T2* (B and D) and FLAIR (C and E) sequences showing that microbleeds are present in older people with DS and may be due to CAA (arrows distinguish edema and hemosiderin positive microbleeds (arrows)). 